\title{
The exotic palm Roystonea oleracea (Jacq.) O.F. Cook as a rural biotype for Rhodnius neglectus Lent, 1954, in Caçu, State of Goiás
}

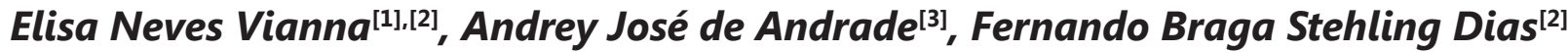 \\ and Liléia Diotaiuti ${ }^{[2]}$
}

[1]. Programa de Pós-Graduação em Medicina Tropical, Faculdade de Medicina, Universidade Federal de Minas Gerais, Belo Horizonte, MG. [2]. Centro de Pesquisas René Rachou, Fundação Oswaldo Cruz, Belo Horizonte, MG. [3]. Faculdade de Medicina, Universidade de Brasília, Brasília, DF.

\begin{abstract}
Introduction: Rhodnius neglectus is a triatomine that colonizes different palm species. In this study, we aimed to describe the presence of this triatomine bug in the royal palms (Roystonea oleracea) in a rural region of the State of Goiás. Methods: Palm infestation was investigated by dissecting the palms or by using live-bait traps. Results: Two palm trees were infested by $R$. neglectus negative for Trypanosoma cruzi, the etiological agent for Chagas disease. In the study area, R. neglectus is frequently found in households. Conclusions: The adaptation of this species to palm trees introduced in Brazil for landscaping purposes poses another challenge for controlling the vectors of Chagas disease.
\end{abstract}

Keywords: Triatomine bugs. Infestation. Palm trees.

Rhodnius neglectus Lent, 1954 (Hemiptera, Triatominae) is a triatomine bug that mainly inhabits palm trees in the Brazilian Savanna ${ }^{1-3}$, Pantanal, and Caatinga biomes ${ }^{4}$. This species is found in the palm trees of the genera Mauritia, Acrocomia, Attalea, Oenocarpus, and Copernicia ${ }^{3,5}$ and Roystonea and Livistona, exotic genera used for landscaping purposes in urban environments ${ }^{6,7}$. In Midwestern Brazil, $R$. neglectus is frequently detected in wild native palm trees near reservoirs, and it is a vector of Trypanosoma cruzi (trypanosomatids), the etiological agent of Chagas disease ${ }^{2,3}$. It is significantly more frequent in rural households (intradomiciles) in the State of Goiás than in other regions where it has been reported ${ }^{8}$. This species might occasionally have high rates of $T$. cruzi infection in the natural environment, as has been reported in the babaçu palm (Attalea speciosa) in Uberaba, State of Minas Gerais ${ }^{2}$. Thus, it is considered a relevant target for research on the ecology of vectors.

The southern region of Goiás, Brazil, where the Caçu municipality is located, within the microregion of Quirinópolis, is characterized by widely deforested areas with small fragments of forest that are used for extensive monoculture plantations (e.g., sugarcane and soybeans) and livestock subsistence. Native

Address to: Dr ${ }^{\text {a }}$ Elisa Neves Vianna. Programa de Pós Graduação em Medicina Tropical/FM/UFMG. Av. Prof. Alfredo Balena 190, 30130-100 Belo Horizonte, MG, Brasil.

Phone: 5531 3409-5000

e-mail: ramarrina@gmail.com

Received 23 October 2013

Accepted 25 March 2014 palm trees such as gueiroba (Syagrus oleracea) and bacuri (Attalea phalerata) are widely found close to dwellings in this region, and they are used for cooking. In this study, we aimed to describe the occurrence of $R$. neglectus in exotic palm trees (Roystonea oleracea) in the rural areas of Caçu, State of Goiás, Brazil, where hydroelectric power plants are being built.

The Caçu municipality has 13,283 inhabitants, land area of $2,251 \mathrm{~km}^{2}$, population density of 5.9 inhabitants $/ \mathrm{km}^{2,9}$, and an altitude of $486 \mathrm{~m}$. According to the Köppen climate classification categories, the climate in Caçu is AW ( $\mathrm{A}=$ tropical wet and $\mathrm{W}=$ dry or savanna climate), with two distinct seasons: dry winter and humid summer. The annual average temperature is around $21^{\circ} \mathrm{C}$, and the annual average rainfall ranges between 1,200 and $1,800 \mathrm{~mm}$. This study was performed in two rural areas located near the Claro River: the first was conducted near the hydroelectric power plant (HPP) of Caçu (18 $31^{\prime} 46^{\prime \prime} \mathrm{S}$ and $51^{\circ} 09^{\prime} 00^{\prime \prime} \mathrm{W}$ ), and the second, $35 \mathrm{~km}$ away, near the Barra dos Coqueiros HPP $\left(18^{\circ} 43^{\prime} 24^{\prime \prime} \mathrm{S} \text { and } 51^{\circ} 00^{\prime} 11^{\prime} \mathrm{W}\right)^{10}$.

Forest fragments or palm trees in pastures were selected close to households in localities that had been subjected to deforestation for the construction of HPPs. The palm trees were randomly selected within a distance of approximately 200-500 $\mathrm{m}$ from the houses on the banks of the Claro River from an area that would become flooded in the future due to a HPP (Figure 1). Sampling was conducted in six rural localities that were characterized by a mixture of highly anthropogenic savanna and palm swamp.

The triatomine bugs were captured during the dry season in September 2009 when deforestation was authorized for the construction of dams. The insects were collected by dissecting palms after receiving approval from the Department 

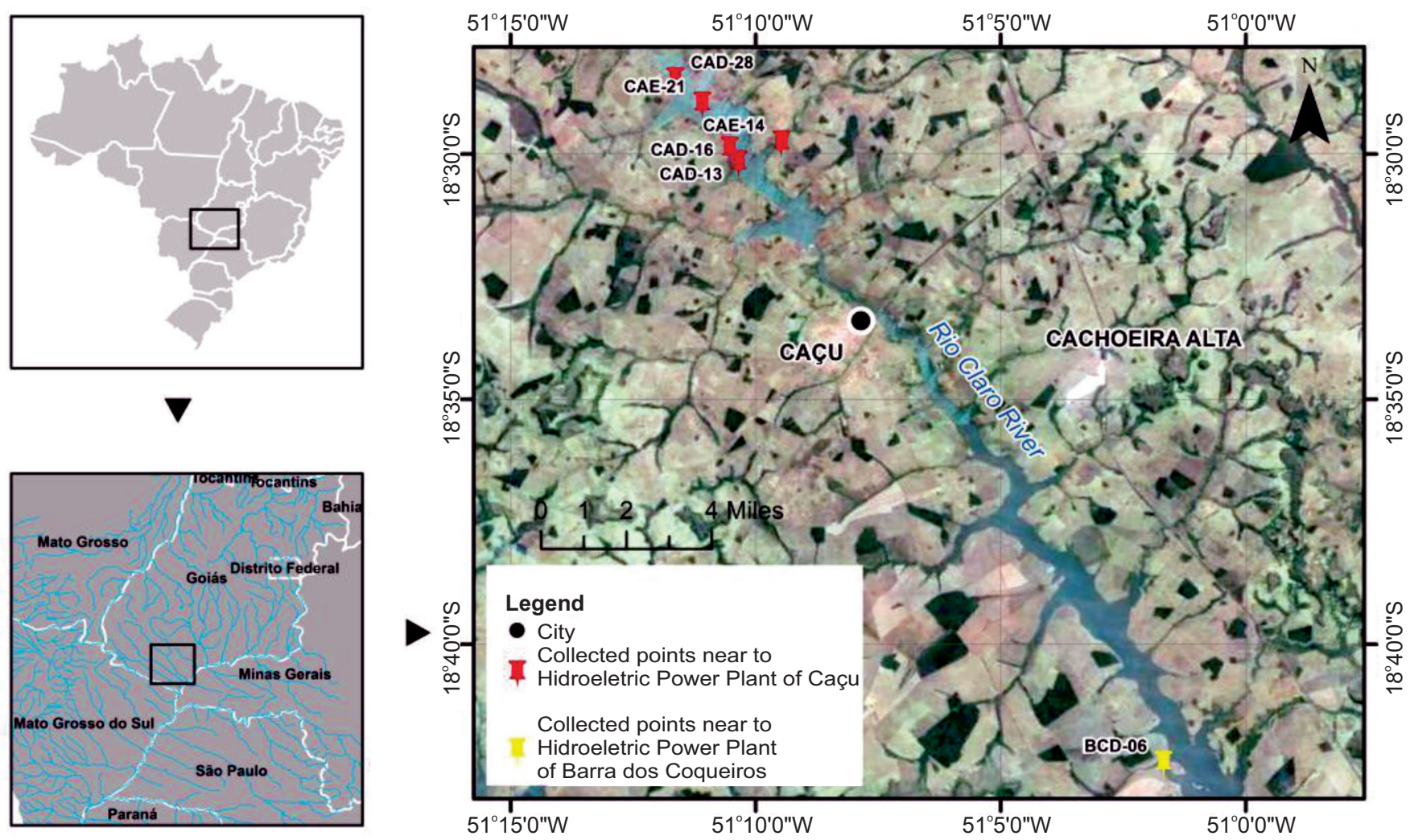

FIGURE 1 - Map of the Caçu municipality, State of Goiás, Brazil, and the regions in the rural localities from where the study palms were sampled.

for the Environment and Water Resources (Secretaria do Meio Ambiente e dos Recursos Hidricos) of the State of Goiás. The palm leaves were cut, and the leaf sheath was removed. All organic material as well as the sheaths were placed on white cloths measuring approximately $10 \mathrm{~m}^{2}$ and thoroughly searched for insects. Four Attalea phalerata, one Mauritia flexuosa (known as buriti), and three royal palms ( $R$. oleracea) were dissected. Furthermore, forty-one traps with chicks as live bait ${ }^{11}$ were placed under thirteen palm trees. Two to three traps were placed in the crown of each palm during the afternoon and removed the following morning approximately $15 \mathrm{~h}$ after each of the localities was chosen. Four specimens of gueiroba (S. oleracea) and nine specimens of $A$. phalerata were examined (Table 1).

All triatomines found were identified ${ }^{12}$, and fresh feces were submitted to parasitological examination to confirm the presence of trypanosomatids under light microscopy (400X magnification). The entire procedure was performed at the Laboratory of Triatomines and Chagas Disease Epidemiology (Laboratório de Triatomíneos e Epidemiologia da Doença de Chagas), René Rachou Research Center/Oswaldo Cruz Foundation (Centro de Pesquisa René Rachou/Fundação Oswaldo Cruz). Information about the profile of household infestation by triatomines over eight non-consecutive years in the region was collected. Such information was obtained from the Center for Endemic Disease Control of the town of Jataí (Núcleo de Apoio ao Controle de Endemias de Jataí-NACE).
All the A. phalerata and M. flexuosa specimens, as well as the palm trees sampled through the live-bait traps, were negative for the occurrence of triatomines. Two royal palms had been infested by $R$. neglectus. Seven nymphs and six adults were collected from one palm tree, and four nymphs were collected from the other. The global infestation rate of palms was 5.5\%, and the average number of triatomines per positive palm was 8.5. The parasitological examination of fresh feces showed no flagellate forms similar to T. cruzi. Bird feces and parrot feathers were found between the leaf sheaths in the canopy of palm trees where the insects were detected and collected. This might suggest that birds are the main food source for $R$. neglectus that inhabit royal palms in this region.

Information about infestation, spread, and infection of T. cruzi via triatomines in the households of the Caçu municipality is limited. Nevertheless, some data could be collected, as shown in Table 2. Triatoma sordida, an ornithophilic species and, currently, the most captured triatomine species in Brazil according to the Chagas Disease Control Program, is predominant in this region, especially in peridomiciles. In the samples analyzed in this study, T. sordida was not identified, as previously reported in palms ${ }^{5}$. As revealed by the Support Center for Endemic Disease Control of Jataí, $R$. neglectus is the second-most captured triatomine species in this region. Moreover, this species is able to colonize peridomestic areas as well as intradomiciles (Table 2), as 
TABLE 1 - Regions in the rural localities of the Caçu municipality, State of Goiás, Brazil, from where the study palms were sampled. Method used to capture triatomine bugs, number of traps placed under palm trees, palms dissected, palm species, and location of palm(s).

\begin{tabular}{lccccc}
\hline Locality & Method & Number of traps & Number of palms & Palm specie(s) & Place \\
\hline BC-D-06 & Live-bait trap & 20 & 20 & Syagrus oleracea and Attalea phalerata & Pasture \\
BC-D-06 & Palm dissection & - & 3 & Syagrus oleracea and Mauritia flexuosa & Palm swamp \\
CA-D-13 & Palm dissection & - & 2 & Syagrus oleracea & Forest \\
CA-D-16 & Palm dissection & - & 3 & Roystonea oleracea & Pasture besides a forest \\
CA-D-14 & Live-bait trap & 4 & 2 & Syagrus oleracea & Peridomicile \\
CA-D-28 & Live-bait trap & 15 & 5 & Syagrus oleracea and Attalea phalerata & Pasture and Peridomicile \\
CA-E-21 & Live-bait trap & 2 & 1 & Syagrus oleracea & Peridomicile \\
\hline Total & & 41 & 36 & &
\end{tabular}

BC-D: Barra dos Coqueiros, right bank; CA-D: Caçu, right bank; CA-E: Caçu, left bank. Each locality belonged to a construction area of one of the hydroelectric power plants (Barra de Coqueiros or Caçu) and was enumerated by previous studies to investigate the environmental impact in the region.

TABLE 2 - Number of specimens of Rhodnius neglectus collected in 2000, 2001, 2002, 2004, 2005, 2006, 2007, and 2012 from the domiciliary location in the town of Caçu, State of Goiás, Brazil.

\begin{tabular}{|c|c|c|c|c|c|c|c|c|c|}
\hline & \multicolumn{2}{|c|}{ Intradomicile } & \multicolumn{2}{|c|}{ Peridomicile } & \multicolumn{2}{|c|}{ Adults } & \multicolumn{2}{|c|}{ Nymphs } & $\begin{array}{c}\text { Total } \\
\text { n }\end{array}$ \\
\hline Rhodnius neglectus & 94 & 25.0 & 160 & 12.0 & 192 & 16.0 & 62 & 12.0 & 254 \\
\hline Triatoma sordida & 282 & 75.0 & 1,128 & 84.5 & 974 & 81.0 & 436 & 86.0 & 1,410 \\
\hline Others* & 0 & 0.0 & 46 & 3.5 & 38 & 3.0 & 8 & 2.0 & 1,710 \\
\hline
\end{tabular}

Source: Support Center for Endemic Disease Control of Jataí, Office of Policies for Full Health Care, State Secretary of Health (State of Goiás). Result of surveys in peridomiciles and intradomiciles, according to the Manual of Technical Norms of the Program for the Control of Chagas Disease ${ }^{15}$. No species was identified by entomologic surveillance.

reported in other regions of the State of Goiás ${ }^{3,8}$. The royal palm is native to the Antilles; it was introduced in Brazil for landscaping purposes. In Colombia, Rhodnius prolixus abundantly colonizes plantations of Elaeis guineense, a palm tree from Africa used for the extraction of a type of oil widely used for cooking (known as dendê in Brazilian cuisine $)^{13}$. This shows that other triatomine species can adapt to exotic ecotopes in rural and agricultural areas. In 2007, in the municipality of Araçatuba, the occurrence of $R$. neglectus was described to colonize $R$. oleracea in urban areas ${ }^{6}$. In 2012, specimens of the exotic palm Livistona australis were also found to be infested by $R$. neglectus in the town of Monte Alto, in the State of São Paulo ${ }^{7}$. These studies emphasize the potential for $R$. neglectus to adapt to new habitats.

During the dissection of the royal palms, feathers of Psittacidae species were observed, and there was no trace of remains from other vertebrates. This might be the reason for the absence of $T$. cruzi infection in $R$. neglectus, due to its probable association with birds. This palm tree is gorgeous and has a leafy canopy; thus, it is attractive to birds for nesting purposes and serves as a food source for $R$. neglectus. The presence of vertebrates such as mammals and birds within the palm is one of the factors for the establishment and growth of the triatomine colonies $^{14}$. Future studies need to be performed in other seasons of the year, since the dynamics of these vertebrates is seasonal; such investigations might show associations of $R$. neglectus with different vertebrates present in Caçu, as reported for other regions ${ }^{3,13,14}$. In other palm species surveyed, the presence of nests and/or traces (i.e., feathers or feces) of animals were not observed.

Data of the Program for the Control of Chagas Disease ${ }^{15}$ showed that $R$. neglectus is frequently found in the artificial environment of the region, including intradomiciles, which is consistent with the behavior of the species in the State of Goiás ${ }^{8}$. The proximity of palm trees to households (300-700m) is an important factor while investigating the eco-epidemiology of Chagas disease, as shown in the State of Tocantins, a state neighboring the study area of this research and Goiás ${ }^{3}$. This suggests that $R$. neglectus can invade households and thus colonize there. Royal palm trees are usually planted close to households because of their beauty and scenic value. The colonization of these palm trees, therefore, indicates a potential risk of spreading $R$. neglectus in nature, especially in 
an environment close to humans, as has been already reported ${ }^{6}$. In highly modified areas, as those affected by the construction of two HPPs, exotic palms might play a key role in the relationship between health and environment. Exotic palm trees widely used in landscaping in urban and rural environments might represent another challenge for controlling synanthropic triatomines in Brazil.

This study strictly followed the ethical codes of Brazil. The sampling was performed in complete compliance with the Brazilian laws (license number, 0941/2008, SEMARH Secretaria do Meio Ambiente e dos Recursos Hídricos - and Goiás Environmental Agency; Case Number, 5601.03449/2007-4).

\section{ACKNOWLEDGMENTS}

We would like to thank the entire team of environmental consultants from companies Bio 3 and Visão Ambiental for their logistical and financial support. We also thank the Secretaries of Health of the municipalities of Caçu, Jataí, and Rio Verde for the information provided and guidance, and Christian Resende for drawing the maps of the areas under study. We are also grateful to Maurício Simas Coelho for his help with fieldwork.

\section{CONFLICT OF INTEREST}

The authors declare that there is no conflict of interest.

\section{FINANCIAL SUPPORT}

René Rachou Research Center/Oswaldo Cruz Foundation (Centro de Pesquisa René Rachou/Fundação Oswaldo Cruz, CpqRR/ FIOCRUZ), Bio3: Environment and projects, Gerdau Açominas.

\section{REFERENCES}

1. Carcavallo RU, Curto De Casas SI, Sherlock IA, Galíndez-Girón I, Jurberg J, Galvão $\mathrm{C}$, et al.. Distribuição geográfica e dispersão altitudinal. In: Carcavallo RU, Galíndez Girón I, Jurberg J, Lent H, editors. Atlas of Chagas' disease vector in the Americas. Vol III. Rio de Janeiro: FIOCRUZ; 1998. p. 747-792.

2. Barretto MP. Epidemiologia. In: Brener Z, Andrade Z, editors. Trypanosoma cruzi e doença de Chagas. Rio de Janeiro: Editora Guanabara Koogan, 1979. p. 89-151.
3. Abad-Franch F, Monteiro FA, Jaramillo N, Gurgel-Gonçalves R, Dias FBS, Diotaiuti L. Ecology, evolution and the long term surveillance of vectorborne Chagas disease: a multi-scale appraisal of the tribe Rhodniini (Triatominae). Acta Trop 2009; 110:35-41.

4. Batista TA, Gurgel-Gonçalves R. Ecological niche modelling and differentiation between Rhodnius neglectus Lent, 1954 and Rhodnius nasutus Stål, 1859 (Hemiptera: Reduviidae: Triatominae) in Brazil. Mem Inst Oswaldo Cruz 2009; 104:1165-1170.

5. Gurgel-Gonçalves R, Ribeiro Jr G, Costa Neto EM. Infestation of palm trees by triatomines (Hemiptera: Reduviidae) in the state of Bahia, Brazil. Entomo Brasilis 2012; 5:227-231.

6. Rodrigues VLCC, Silva RA, Wanderley DMV, Carvalho ME, Pauliquevis Jr C. Detecção de triatomíneos da espécie Rhodnius neglectus em área urbana de municípios da região de Araçatuba. Bol Epidemiol Paul 2009; 6:20-23.

7. Carvalho DB, Almeida CE, Rocha CS, Gardim S, Mendonça VJ, Ribeiro AR, et al. A novel association between Rhodnius neglectus and the Livistona australis palm tree in an urban center foreshadowing the risk of Chagas disease transmission by vectorial invasions in Monte Alto City, São Paulo, Brazil. Acta Trop 2014; 130:35-38.

8. Oliveira AWS, Silva IG. Distribuição geográfica e indicadores entomológicos de triatomíneos sinantrópicos capturados no Estado de Goiás. Rev Soc Bras Med Trop 2007; 40:204-208.

9. Instituto Brasileiro de Geografia e Estatística. Censo 2012 [Internet]. 2012; [Cited 2013 August 9]. Available at: http://www.censo 2012.ibge. gov.br.

10. Sousa-Júnior WC, Sinisgalli PAA, Bermann ATC, Garcia L, Ghaz M, Cruz P, et al. Análise da Viabilidade Técnica e Ambiental de AHEs no Sudoeste de Goiás. Relatório Final São José dos Campos/SP [Internet]. 2005; [Cited 2013 August 9] Available at: http://www.geomatica.ita.br/ wilson/artigos/AHES_GO_02abr2005_final.pdf.

11. Noireau F, Abad-Franch F, Valente SAS, Dias-Lima A, Lopes CCM, Cunha V, et al. Trapping Triatominae in silvatic habitats. Mem Inst Oswaldo Cruz 2002; 97:61-63.

12. Lent H, Wygodzinsky P. Revision of Triatominae (Hemiptera: Reduviidae), and their significance as vectors of Chagas disease. Bul Am Mus of Nat Hist 1979; 163:127-520.

13. Guhl F. Ecoepidemiologia de La fauna de triatominos (Reduviidae: Triatominae) en Colombia y su importancia para los programas de control. In: Taller del Cono Sur actualización de la tripanosomiasis americana, 1, 2007, Asunción, Paraguay. Libro de resúmenes. Universidad Nacional de Asunción 2007. p. 207-211.

14. Gurgel-Gonçalves R, Cuba-Cuba CA. Estrutura de populações de Rhodnius neglectus (Lent) e Psammolestes tertius (Lent \& Jurberg) (Hemiptera, Reduviidae) em ninhos de pássaros (Furnariidae) presentes na palmeira Mauritia flexuosa no Distrito Federal, Brasil. Rev Bras Zool 2007; 24: 157-163.

15. Superintendência de Campanhas de Saúde Pública, Divisão de Doença de Chagas. Manual de Normas Técnicas da Campanha de Controle da Doença de Chagas. Brasília, DF: Ministério da Saúde; 1980. 